\title{
A Sociocultural Approach and Globalisation-related Topics in Teaching English in Japan
}

\author{
Liang Morita ${ }^{1}$ \\ ${ }^{1}$ Faculty of Communication, Nagoya University of Commerce and Business, Nagoya, Japan \\ Correspondence: Liang Morita, Faculty of Communication, Nagoya University of Commerce and Business, 4-4 \\ Sagamine, Komenoki-cho, Nisshin-shi, Aichi, 470-0115, Japan. Tel: 81-561-73-2111. E-mail: liang@nucba.ac.jp
}

Received: September 4, $2014 \quad$ Accepted: September 14, $2014 \quad$ Online Published: September 14, 2014

doi:10.5430/ijelt.v2n1p1 URL: http://dx.doi.org/10.5430/ijelt.v2n1p1

\begin{abstract}
In general the level of proficiency of English in Japan is not very high. The causes may be manifold and complex but one of them is certainly the grammar-translation method used in teaching English. In this method, most of class time is spent on word-by-word translation of English texts into Japanese. This paper presents a preliminary and exploratory study of a sociocultural approach and globalisation-related topics which could complement the grammar-translation method. It also provides a descriptive account of the lessons. The sociocultural approach is mostly based on social constructivism, to which Lev Vygotsky contributed significantly. The learning of content, in this case about globalisation, as well as language comes under content and language integrated learning (CLIL). The study was conducted in six English communication classes at Nagoya University, a top national university. A total of 109 undergraduates participated. The results indicate that the sociocultural approach motivates the students to learn English and seek for higher communicative skills and they perceive globalisation-related topics as relevant to the ability to function in intercultural contexts.
\end{abstract}

Keywords: English teaching, Japan, intercultural contexts, sociocultural approach

\section{Introduction}

In general the level of proficiency in English in Japan is not very high. Japan often ranks near the bottom in TOEFL scores in Asia (Morita, 2010) and many Japanese participants in international conferences are unable to express themselves in English or make themselves understood. Yano (2011) describes the Japanese as being unable to use English in business negotiations, academic presentations or discussions. Foreigners visiting or living in Japan also remark on the lack of English communicative skills (Morita, 2013). The causes may be manifold and complex but one of them is certainly the grammar-translation method used in teaching English. This paper presents a preliminary and exploratory study of a sociocultural approach and globalisation-related topics in teaching English which could be used to complement the grammar-translation method. It also includes a descriptive account of the lessons.

In the grammar-translation method, most of class time is spent on word-by-word translation of English texts into Japanese. Students learn the rules of grammar and they translate to and from the target language, English (Griffiths, 2011). Reading and writing, accuracy and teacher direction are emphasised. Explanations are provided in the students' first language, Japanese. Teachers teach by means of explaining grammar rules, translation, vocabulary lists, exercises, memorisation and correcting errors. This method is still common and deeply entrenched in Japanese schools (King, 2013; Stewart \& Miyahara, 2011). The method is less effective because it emphasises the memorisation of grammatical rules over the learning of what is spoken or written (O'Donnell, 2003) and its repetitive and monotonous nature contributes to learners' low motivation (Hayashi, 2005; Kikuchi \& Sakai, 2009).

Language is usually used in a sociocultural context. Grammar-translation is unusual in the sense that the sociocultural context is ignored and students focus grammar and vocabulary only. Language, culture and society and so closely intertwined that it is impossible to teach a language well without acknowledging the sociocultural context in which it is used. This is illustrated by Romaine (2001) using the sentence 'How about meeting for a drink later, honey?' The same words can take on different meanings and significance depending on who uses them and in what sociocultural context. The sentence could be said by a male customer to a waitress he does not know or by a woman 
to her husband as they discuss their schedules for the day. Much of language is ambiguous and depends on context for its interpretation. In Hymes' (1972) development of the concept of communicative competence, he emphasised the need to pay attention to the ability to use language appropriately, i.e. sociolinguistic competence. In addition, Dornyei (1994) advocated a sociocultural component in the syllabus to raise learners' motivation in the foreign language classroom. Whitsed and Wright (2011) found that Japanese students limited English to the context of entrance examinations and did not see it as a living language. A sociocultural approach will change that perception.

The sociocultural approach is mostly based on social constructivism, to which Lev Vygotsky contributed significantly. Vygotsky $(1978,1986)$ recognised that an individual's cognitive system is a result of communication in social groups and cannot be separated from social life. According to later social constructivists, the context (i.e. setting and activity) in which knowledge is developed cannot be separated from learning (Lave \& Wenger, 1991; Rogoff \& Lave, 1984). Learning is fully situated or located within a given context.

The sociocultural approach will help learners develop cultural awareness (CA). At the most basic level, CA is a conscious understanding of the role culture plays in language learning and communication in both first and foreign languages (Baker, 2012). In order to foster CA, language and culture should be taught together, and the relationship between them explicitly explored with learners. Basic CA includes an awareness of the role culture and context play in any interpretation of meaning. It has the potential of developing into advanced CA and then into intercultural awareness (ICA), which is most relevant to intercultural communication. Baker (2012) defines ICA as a conscious understanding of the role culturally-based forms, practices and frames of understanding can have in intercultural communication, and an ability to put these conceptions into practice in a flexible and context-specific manner in real-time communication.

The sociocultural approach has proven useful in the teaching, learning and development of French sociolinguistic competence (Compernolle \& Williams, 2012). The approach helped second language learners of French in the US to understand the variable use of the negative morpheme ne in verbal negation and, which led to the development of their performance abilities. It also improved EFL learners' writing quality (Rahimi \& Noroozisiam, 2013).

Intercultural communication is going to be commonplace in Japan soon. The Japanese population is aging and declining rapidly and the UN estimates that replacement migration needs to be at as high as 650,000 a year to stablise the population. An anonymous reviewer of this paper pointed out that although the number of foreigners is increasing, $60 \%$ of them are from China and Korea, 20\% from Brazil and Peru and 20\% from other countries with Filipinos making up the majority. English therefore does not appear to be particularly useful tool for the Japanese to communicate with these foreigners. However, in Kirkpatrick's (2011) plenary speech, he points out that although Bahasa Indonesia and Mandarin are the two most widely-spoken Asian-based lingua francas in East and Southeast Asia, for the moment, English remains the region's (and world's) primary lingua franca in that English is the language most commonly used by people who do not share a mother tongue.

Globalisation and internationalisation are hotly-debated topics in Japan. Since these phenomena have potentially far-reaching and long-lasting effects on the country, it is important that students understand the issues involved. Japan is ambivalent towards globalisation (Yamagami \& Tollefson, 2011). It is perceived an opportunity as well as a threat. The government emphasises that individuals and the nation must develop new skills (especially in English and technology) but at the same time, Diet (parliament) discourse articulates the threats that globalisation presents: violent crime, reduced personal and national security, and a sense of loss and uncertainty about the future. The Japanese are aware that in order to remain economically competitive, it must open up, instigate reforms and embrace globalisation in all its aspects. However, there is still a strong tendency to close in, reject global norms and standards, and retreat inwards (Burgess, 2013). Both government and society are inward-looking and remain rooted in an insular worldview that sees globalisation as an external process owned by somebody else.

What the Japanese government claims to promote can be quite different from what it really wants to achieve (Hashimoto, 2009). Although Japan appears to embrace internationalisation, there is at the same time an emphasis on national culture and tradition. The focus is on the exportability of Japanese culture to the world or the promotion of Japaneseness in the international community. Likewise in the discourse on English, the learning of English as a lingua franca to increase global literacy is carried out within the framework of Japanese culture. The goal is enrichment of Japanese language and culture through interaction with other languages and cultures.

Since English is often cited as the language of globalisation, the English-language classroom is an appropriate place to explore the issues related to globalisation. The learning of content as well as language comes under content and language integrated learning (CLIL) or content-based language teaching (CBLT). It is a dual-focused learning and teaching approach in which a non-language subject is taught through a foreign language, with the dual focus being 
on acquiring subject knowledge and competences as well as skills and competences in the foreign language (Georgiou, 2012). There is a range of CLIL settings along a continuum varying from those that emphasise content to those that emphasise language. The present globalisation-related topics study is located around the middle of the continuum where the author attempts to achieve a balance between content and language.

CLIL crosses a wide range of international contexts and instructional settings, including elementary, secondary and post-secondary institutions (Lyster \& Ballinger, 2011). In Japan, content-based EFL courses have been introduced at post-secondary levels where a task-based approach to CLIL has shown considerable promise in courses in comparative culture (Lingley, 2006). It also provides a refreshing change from teacher-led lecture formats in geography and sociology courses (Moriyoshi, 2010). In English immersion, English as an international language is the main target of CLIL (Bostwick, 2001).

The study is introduced in Section 2, followed by the sociocultural approach in Section 3 and the globalisation-related topics in Section 4. Discussion in Section 5 concludes the paper.

\section{The Study}

Japanese universities can be divided into three categories: national (run by the state), municipal (run by local authorities) and private (King, 2013). Out of a total of 773 universities, 86 are national, 92 are municipal and 595 are private. Nagoya University is a national university. An anonymous reviewer pointed out that national universities have their peculiarities and are subject to a string of regulations and conditions dictated by the ministry. In the 10 years the author taught at Nagoya, she has observed inflexibility in its English education as well as widespread use of the grammar-translation method. These do not apply in the same rigidness to private universities, many of which are renowned and successful in implementing other ways of teaching English. Universities specialising in foreign language education have achieved remarkable success in their programmes, setting new standards for university education in general. For many years, concerned parents have been urging for a more usable English education starting in pre-school, which is slowly rendering its effects on the schooling system as a whole.

The sociocultural approach study was conducted in a semester when the author was assigned three English communication classes for first and second year undergraduates. The first class was for Engineering students (18 students), the second for Literature students (20 students) and the third for Science students (16 students). A total of 54 students participated in the study.

The globalisation-related topics study took place a year later. The author again taught three communication classes for first and second year undergraduates. The classes were for Agricultural Science students (17 students), Economics students ( 21 students) and Engineering students (17 students). In total there were 55 students.

Towards the end of each of the two semesters, the students were given a copy of Likert-type questionnaire with space for comments developed by the author. Although the classes were taught in English, the questionnaire was written in Japanese, the students' native language, to encourage them to express their thoughts and opinions freely. The survey was anonymous and they were told that participation was voluntary and was not related to their grades in any way.

\section{The Sociocultural Approach Study}

At the time this study was conducted, Nagoya University emphasised English communicative skills. This was consistent with government efforts to improve English education in the Reform Acts of 1989 and 2002, which stressed a communicative approach to English teaching (Seargeant, 2009). The questionnaire consisted of four statements, and each statement is on a different aspect of the sociocultural approach adopted. The responses allow the author to look into the degree of students' motivation to learn English and to seek for higher communicative skills, but not necessarily whether the sociocultural approach actually helped them with enhancing their communication skills. The statements are:

1. The study of language use in television programmes and films helped improve my English communicative skills.

2. The study of sociocultural differences helped improve my English communicative skills.

3. The study of language use in different contexts/situations helped improve my English communicative skills.

4. The use of internet in the English language helped improve my English communicative skills.

The students chose from the responses strongly disagree, disagree, agree and strongly agree. 


\subsection{Getting to Know a Different Society/Culture}

Research has shown that learners are drawn to popular culture originating from English-speaking countries and have shown greater interest and motivation when such culture is presented in the classroom (Cheung, 2001). English teachers' use of popular culture is a key to effective teaching and learning.

The students were introduced to several unfamiliar aspects of society/culture of English-speaking countries through the use of authentic videos. In one lesson on socioeconomic class, they saw a few scenes from a popular American series in which a teenager from a middle-class background experienced peer pressure from her upper-class friends. She felt she had to keep up with her wealthier friends in her consumption of luxury goods and services, and eventually committed theft. The students were asked to define peer pressure, social class and the factors which determine class membership. They also compared social class in Western industrialised societies with that in Japan and found that factors such as income, education and profession may define class membership in the former but not in Japan.

The author felt it was easier for the students to learn the meaning of words and phrases when they were provided with a relevant context. A case in point is the word circle. In the above video, circle was used to refer to someone's friends and the students understood the meaning easily. It was a good opportunity for the author to point out that in the context of Japanese university life, the word had a slightly different meaning. A sports club such as baseball club or tennis club refers to the official university team, while baseball circle or tennis circle refers to an informal organisation formed by students which is usually of a lower standard than the club. Having a context also made it easier for students to understand metaphors such as landmine, circling the drain and to have a lot on one's plate in other videos.

In a different lesson on university admissions, the students watched parts of an episode from the same series in which high school students were applying to Ivy League universities and attending screening interviews. This was followed by discussions on Ivy League institutions in the US and the Russell Group in Britain. The class also compared the admissions process in the US, UK and Japan and learned about the SAT, A-levels and International Baccalaureate. Their conclusion was that different systems work well in different places and although the US and UK evaluate their applicants more thoroughly, the Japanese entrance examinations system has its merits.

\subsubsection{British versus American English}

In general, English teachers at Japanese high school do not introduce the phenomenon of geographical variation in English. To develop learners' communicative capabilities, some sociolinguists are calling for the introduction of different varieties of English into ELT (Suzuki, 2011). They maintain that being exposed to several varieties in the classroom can help learners become aware that the success of communication with other English speakers does not necessarily rely on the forms of English they produce, and their developed awareness would help them focus more on their own communication skills. However, it would be impractical to demand that teachers teach several varieties of English, since teacher training programmes in Japan still present only standard American and/or standard British English as a single normative variety of English (Suzuki, 2011). In addition, many teachers tend to rely on what they themselves were taught.

The lesson focused on a British actor who played the role of an American in a video. After listening to the actor's American pronunciation in class, the students went to the computer laboratory to search for video clips on the internet in which the actor spoke his native British English. Most of the students found it a challenge to understand English spoken at a natural speed but managed to note down a few differences between British and American pronunciation. After returning to the classroom, they were asked to reflect on whether British or American English was superior and the reasons for their answer. The author pointed out that all varieties were linguistically equal and the students should strive for intelligibility and clarity rather than imitation of any variety of English. In addition to the differences between the two varieties of English in pronunciation, vocabulary and grammar, the discussion in class included the source of English borrowings in Japanese. Although the students thought that the vast majority of the borrowings were from American English, it turned out that some (such as cinema) were from British English on closer inspection. The lesson concluded with advice from the author that although it was acceptable to mix British and American English in casual speech and writing, consistence should be maintained in more formal contexts.

\subsection{Sociocultural Similarities/Differences}

In one lesson, the students watched a few scenes from an American series in which a young American woman found it difficult to be direct with her superior at work about some issues. This challenged the widespread belief in Japan 
that Americans are direct in communication and the Japanese are indirect. The students worked on providing a list of reasons which explained why people in general found it difficult to be direct. They found that these reasons applied to most people, including Americans. The discussion continued with how easy it was to over-generalise based on the behaviour of a few members of a group, and how this led to the formation of stereotypes and subsequently racial discrimination.

At the beginning of the semester, the topic small talk was used to break the ice. The students were introduced to small talk in English as well as to the differences in small talk across cultures. Some students were quick to point out that even though it was acceptable to ask about one's blood type in Japanese small talk, it may not be acceptable in other cultures. Later in the semester when the class covered job interviews, the author led the discussion on how confidence, directness, individualism and initiative were valued in US workplaces but not necessarily in Japan. In collectivist societies such as Japan, the group has priority over individuals.

\subsection{English Use in Different Contexts}

Due to the way the students have been taught, most of them are unaware of how English speakers change their style or register depending on the situation. The contexts covered in this study include job interviews and business negotiations. In the former, the students learned that they had to keep their answers brief and concise, include concrete data, ask questions (in order to show interest) and research the company. Most of them were not used to speaking in a confident and direct way. When asked a question, many struggled in presenting the main point first and the background or explanation later. In Japanese they are accustomed to providing the background or explanation first and then arriving at the main point at the end. The students also worked on word choice to make their responses as short and clear as possible.

In negotiations, they learned how to establish and maintain a climate of cooperation with their language style. The class again spent some time on word choice and discussed the different effects words convey. Many students were unsure how to be clear and unambiguous but improved as the lesson progressed.

\subsection{Internet Use}

Although young people in East Asia have informally embraced Information and Communication Technologies (ICTs), they learn in formal contexts dominated by traditional models of learning (Richards, 2004). In addition to being the exemplary medium of new ICTs, the internet is increasingly a dominant cultural context for the younger generation. Due to its ability to cut across physical boundaries and geographical distances, the internet is capable of connecting people from different cultural backgrounds around the world. It is increasingly recognised as a vehicle for globalisation and internationalisation in education (Davis, 1999).

The vast majority of the students used the internet in the Japanese language. When small talk was covered, they were told to search for cultural differences presented in English websites. In job interviews, they looked for authentic job advertisements written in English. They also visited university websites outside Japan and chose one they most liked to attend. Although the students were resistant to the idea of using the English language on the internet at the beginning and found it challenging, many felt it was a good experience.

\subsection{Applying the Lesson}

To avoid making the students passive learners, they had to apply what they learned at the end of each lesson. In small talk, they created and presented a skit about a misunderstanding due to cultural differences. At the end of the lesson on being direct, the students had to describe a situation in which they felt it was difficult to be direct and suggest appropriate things to say. In business negotiations, they created and presented their original negotiation. After watching a few scenes from a film which featured the struggles of television producers to raise ratings and main high standards at the same time, the students prepared a news story and presented it in a style they chose. The styles ranged from sensational and entertaining at one extreme to informative and educational at the other, and the presenters explained their choice.

\subsection{Students' Responses}

The results in the Engineering, Literature and Science classes are presented in Tables 1, 2 and 3, and they are combined in Table 4. 
Table 1. Engineering students in the sociocultural approach study

Engineering $(n=18)$

1. The study of language use in television programmes and films helped improve my English communicative skills.

2. The study of sociocultural differences helped 0 improve my English communicative skills.

3. The study of language use in different contexts/situations helped improve my English communicative skills.

4. The use of internet in the English language 0 helped improve my English communicative skills.

$\begin{array}{ll}\text { Strongly } & \text { Disagree } \\ \text { disagree } & \\ 0 & 0\end{array}$

Agree

Strongly agree

$15(83.3 \%) \quad 3(16.7 \%)$

0

$16(88.9 \%) \quad 2(11.1 \%)$

0

0

$14(77.8 \%) \quad 4(22.2 \%)$

$6(33.3 \%) \quad 8(44.4 \%) \quad 4(22.2 \%)$

Table 2. Literature students in the sociocultural approach study

Literature $(n=20)$

1. The study of language use in television

programmes and films helped improve my

English communicative skills.

2. The study of sociocultural differences helped 0 improve my English communicative skills.

3. The study of language use in different contexts/situations helped improve my English communicative skills.

4. The use of internet in the English language helped improve my English communicative skills.

\section{Strongly}

disagree

0

0

Disagree

$1(5 \%)$

0

0

$1(5 \%)$

$5(25 \%)$

$10(50 \%)$
Agree Strongly agree

$12(60 \%) \quad 7(35 \%)$

$13(65 \%) \quad 7(35 \%)$

Table 3. Science students in the sociocultural approach study Science $(n=16)$

Strongly
disagree
0

1. The study of language use in television

$$
0
$$

Disagree

Agree

Strongly agree

programmes and films helped improve my

0

$15(93.8 \%) \quad 1(6.3 \%)$

English communicative skills.

2. The study of sociocultural differences helped 0

0

$13(81.3 \%) \quad 3(18.8 \%)$

improve my English communicative skills.

3. The study of language use in different

0

0

$15(93.8 \%) \quad 1(6.3 \%)$

contexts/situations helped improve my English communicative skills.

4. The use of internet in the English language helped improve my English communicative skills. 
Table 4. All students in the sociocultural approach study

all $(\mathrm{n}=54)$ Strongly

Disagree

Agree

Strongly

disagree

1. The study of language use in television

0

$1(1.9 \%)$

agree

programmes and films helped improve my

English communicative skills.

2. The study of sociocultural differences helped 0

improve my English communicative skills.

3. The study of language use in different

0

$43(79.7 \%) \quad 11(20.4 \%)$

contexts/situations helped improve my English

communicative skills.

4. The use of internet in the English language

$1(1.9 \%)$

$15(27.8 \%)$

$29(53.7 \%)$

$9(16.7 \%)$

helped improve my English communicative

skills.

Although the sample size is small, the results indicate that the four aspects of the sociocultural approach motivate the students to learn English and seek for higher communicative skills. The results for the first three aspects (the study of language use in television programmes and films, the study of sociocultural differences and the study of language use in different contexts/situations) are similar: $77.8 \%-79.7 \%$ agree and $20.4 \%-22.2 \%$ strongly agree (Table 4 ). The numbers for the use of internet in the English language are lower: $53.7 \%$ agree and $16.7 \%$ strongly agree. The lower numbers are probably due to unfamiliarity of English as language of the internet. A vast majority of the students use Japanese in cyberspace. Several students complained that navigating the internet in English was extremely challenging.

\section{The Globalisation-related Topics Study}

At the time this study was conducted, the term global human resources (gurobaru jinzai in Japanese) was a buzzword in the media, following government use of the term (The Council on Promotion of Human Resource for Globalization Development, 2011). One characteristic of global human resources is their ability to function in intercultural contexts, which is emphasised in Knight and de Wit's (1995) view of preparing students to function in intercultural contexts as a major aspect of the internationalisation of higher education. The questionnaire consisted of five statements, each on a different lesson. The responses allow the author to look into the degree of relevance the students attach to the ability to function in intercultural contexts. The statements are:

1. The lesson on being inward-/outward-looking helped prepare me to function in an international environment.

2. The lesson on assimilation and language shift helped prepare me to function in an international environment.

3. The lesson on gender equality helped prepare me to function in an international environment.

4. The lesson on global chain businesses helped prepare me to function in an international environment.

5. The lesson on consumerism helped prepare me to function in an international environment.

The students chose from the responses strongly disagree, disagree, agree and strongly agree.

\subsection{Being inward-/outward-looking}

There have been reports of Japanese youth turning inwards in the media in the last few years. The government is concerned that the number of Japanese going abroad to study is decreasing and young people increasingly do not want to work overseas (The Council on Promotion of Human Resource for Globalization Development, 2011). In this lesson, the students read an article from The Japan Times on the topic and worked in pairs to create a conversation on being inward-/outward-looking which is supposed to take place between two students. At the end of the conversation, the speakers presented their stand on this issue which they had to justify. The students then presented the conversations to the class. It was a good opportunity to raise awareness and have the students reflect on 
the inward-/outward-looking issues.

\subsection{Assimilation and Language Shift}

The movement of people to different parts of the world is part of the phenomenon of globalisation, as is the giving up one's ancestral language after one settles in a different place where a different language is spoken. Language shift often accompanies assimilation into a society. In the lesson on assimilation and language shift, the students saw a few scenes from a film in which a mother and her daughter moved from Mexico to the US. The mother at first resisted assimilation and learning English but found it increasingly difficult to do so as her daughter became a teenager. She also faced challenges in keeping her daughter from assimilating into American society. At the end of the film, her daughter maintained her Mexican identity as well as the Spanish language, and was considered for admission to a top university. The class debated the pros and cons of assimilation and language shift and discussed whether they would have chosen Mexican or American culture and the corresponding languages if they were the mother. The author introduced the option of being bicultural and bilingual and emphasised their advantages.

\subsection{Gender Equality}

Whenever ranking tables in which countries are ranked according to the extent they have achieved gender equality are published, Japan is usually far from the top. Japan was placed at around the $100^{\text {th }}$ place in a recent table in the Asahi Shinbun. Japan is traditional in the sense that most Japanese women still give up their careers after marriage or childbirth. In the lesson on gender equality, the students saw a video about a young couple living in San Francisco. The woman was offered a post-doctoral researcher's position at Michigan University and her partner gave up his job as chef in a top restaurant in order to relocate with her. They both assumed it would be easy for him to find another chef's position in Michigan. However, he was unable to secure a satisfactory position and was frustrated while the woman thrived in her new environment. The students discussed whose career had priority in a relationship and what they would do if their partners had to relocate like in the film.

\subsection{Global Chain Businesses}

The video in the lesson on global chain businesses was about a young American woman who was embarrassed about working in a big corporate chain and kept it from her friends but was exposed some time later. The class discussed the advantages and disadvantages of corporate chain businesses, how they can be profit-driven and how they drive small businesses out of the market. Many students were not aware that in the US, employment in a large company comes with benefits such as health insurance, dental plans and retirement savings plans. They also made a list of the pros and cons of working in chains such as Starbucks or McDonald's on the one hand and working in independently-owned businesses on the other hand.

\subsection{Consumerism}

Many Japanese young people are influenced by American-style consumerism. The video shown in this lesson was about a marketing company who planted their employees in family units in middleclass communities to market expensive products. The fact that the family members work for a marketing company and are not related by blood is unknown to their friends and neighbours in the communities they live in. The reasoning behind this type of marketing is that these families look like the perfect American family and the people around them want their life and their possessions. The students were asked to reflect on the reasons for making purchases, whether they were out of need or envy. They were asked if they believed advertisements which claimed that certain products brought with them better lifestyles. The students also reflected on their goals in life and on whether accumulating material goods was one of their goals.

\subsection{Students' Responses}

The results in the Agricultural Science, Economics and Engineering classes are presented in Tables 5, 6 and 7, and they are combined in Table 8 .

Table 5. Agricultural Science students in the globalisation-related topics study

\begin{tabular}{|c|c|c|c|c|}
\hline Agricultural Science $(n=17)$ & $\begin{array}{l}\text { Strongly } \\
\text { disagree }\end{array}$ & Disagree & $\begin{array}{c}\text { Agree Strongly } \\
\text { agree }\end{array}$ & $\begin{array}{l}\text { No } \\
\text { response }\end{array}$ \\
\hline $\begin{array}{l}\text { 1. The lesson on being inward-/outward-looking } \\
\text { helped prepare me to function in an }\end{array}$ & 0 & $2(11.8 \%)$ & $\begin{array}{l}123(17.6 \%) \\
(70.6 \%)\end{array}$ & 0 \\
\hline
\end{tabular}

international environment. 


\begin{tabular}{|c|c|c|c|c|}
\hline $\begin{array}{l}\text { 2. The lesson on assimilation and language } \\
\text { shift helped prepare me to function in an } \\
\text { international environment. }\end{array}$ & 0 & $2(11.8 \%)$ & $\begin{array}{l}11 \\
(64\end{array}$ & $\begin{array}{l}3(17.6 \%) 1(5.9 \%) \\
0)\end{array}$ \\
\hline $\begin{array}{l}\text { 3. The lesson on gender equality helped } \\
\text { prepare me to function in an international } \\
\text { environment. }\end{array}$ & 0 & $1(5.9 \%)$ & $\begin{array}{l}9 \\
(52\end{array}$ & $\begin{array}{l}7(41.2 \%) 0 \\
0)\end{array}$ \\
\hline $\begin{array}{l}\text { 4. The lesson on global chain businesses helped } \\
\text { prepare me to function in an international } \\
\text { environment. }\end{array}$ & 0 & $2(11.8 \%)$ & $\begin{array}{l}12 \\
(70\end{array}$ & $\begin{array}{l}2(11.8 \%) 1(5.9 \%) \\
0)\end{array}$ \\
\hline $\begin{array}{l}\text { 5. The lesson on consumerism helped prepare } \\
\text { me to function in an international environment. }\end{array}$ & 0 & $\begin{array}{l}0 \\
(52.9 \%)\end{array}$ & 9 & $8(47.1 \%) 0$ \\
\hline
\end{tabular}

Table 6. Economics students in the globalisation-related topics study

\begin{tabular}{|c|c|c|c|c|}
\hline Economics $(\mathrm{n}=21)$ & $\begin{array}{l}\text { Strongly } \\
\text { disagree }\end{array}$ & Disagree & $\begin{array}{c}\text { Agree Strongly } \\
\text { agree }\end{array}$ & $\begin{array}{l}\text { No } \\
\text { response }\end{array}$ \\
\hline $\begin{array}{l}\text { 1. The lesson on being inward-/outward-looking } \\
\text { helped prepare me to function in an } \\
\text { international environment. }\end{array}$ & 0 & $1(4.8 \%)$ & $\begin{array}{l}10 \quad 10 \\
(47.6 \%)(47.6 \%)\end{array}$ & 0 \\
\hline $\begin{array}{l}\text { 2. The lesson on assimilation and language } \\
\text { shift helped prepare me to function in an } \\
\text { international environment. }\end{array}$ & 0 & $2(9.5 \%)$ & $\begin{array}{l}127(33.3 \%) \\
(57.1 \%)\end{array}$ & \\
\hline $\begin{array}{l}\text { 3. The lesson on gender equality helped } \\
\text { prepare me to function in an international } \\
\text { environment. }\end{array}$ & 0 & $2(9.5 \%)$ & $\begin{array}{l}118(38.1 \%) \\
(52.4 \%)\end{array}$ & \\
\hline $\begin{array}{l}\text { 4. The lesson on global chain businesses helped } \\
\text { prepare me to function in an international } \\
\text { environment. }\end{array}$ & 0 & $2(9.5 \%)$ & $\begin{array}{l}118(38.1 \%) \\
(52.4 \%)\end{array}$ & \\
\hline $\begin{array}{l}\text { 5. The lesson on consumerism helped prepare } \\
\text { me to function in an international environment. }\end{array}$ & 0 & $\begin{array}{l}1(4.8 \%) \\
(57.1 \%)\end{array}$ & $7(33.3 \%)$ & $1(4.8 \%)$ \\
\hline
\end{tabular}

Table 7. Engineering students in the globalisation-related topics study

\begin{tabular}{|c|c|c|c|}
\hline Engineering $(\mathrm{n}=17)$ & $\begin{array}{l}\text { Strongly } \\
\text { disagree }\end{array}$ & Disagree & $\begin{array}{cl}\text { Agree Strongly } & \text { No } \\
\text { agree } & \text { response }\end{array}$ \\
\hline $\begin{array}{l}\text { 1. The lesson on being inward-/outward-looking } \\
\text { helped prepare me to function in an } \\
\text { international environment. }\end{array}$ & 0 & $1(5.9 \%)$ & $\begin{array}{l}115(29.4 \%) 0 \\
(64.7 \%)\end{array}$ \\
\hline $\begin{array}{l}\text { 2. The lesson on assimilation and language } \\
\text { shift helped prepare me to function in an } \\
\text { international environment. }\end{array}$ & 0 & $3(17.6 \%)$ & $\begin{array}{l}112(11.8 \%) 1(5.9 \%) \\
(64.7 \%)\end{array}$ \\
\hline $\begin{array}{l}\text { 3. The lesson on gender equality helped } \\
\text { prepare me to function in an international } \\
\text { environment. }\end{array}$ & 0 & $1(5.9 \%)$ & $\begin{array}{l}14 \quad 2(11.8 \%) 0 \\
(82.4 \%)\end{array}$ \\
\hline $\begin{array}{l}\text { 4. The lesson on global chain businesses helped } \\
\text { prepare me to function in an international }\end{array}$ & 0 & $3(17.6 \%)$ & $\begin{array}{l}10 \quad 4(23.5 \%) 0 \\
(58.8 \%)\end{array}$ \\
\hline
\end{tabular}


environment.

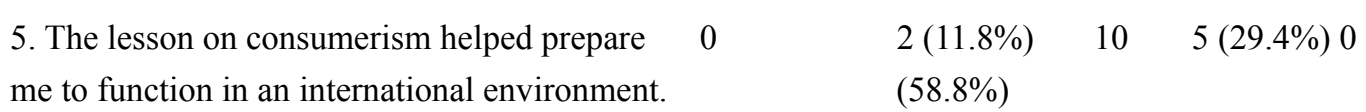

Table 8. All students in the globalisation-related topics study

All $(\mathrm{n}=55)$

1. The lesson on being inward-/outward looking helped prepare me to function in an international environment.

2. The lesson on assimilation and language shift helped prepare me to function in an international environment.

3. The lesson on gender equality helped prepare me to function in an international environment.

4. The lesson on global chain businesses helped prepare me to function in an international environment.

5. The lesson on consumerism helped prepare me to function in an international environment.

\begin{tabular}{|c|c|c|c|c|}
\hline $\begin{array}{l}\text { Strongly } \\
\text { disagree }\end{array}$ & Disagree & Agree & $\begin{array}{l}\text { Strongly } \\
\text { agree }\end{array}$ & $\begin{array}{l}\text { No } \\
\text { response }\end{array}$ \\
\hline 0 & $4(7.3 \%)$ & $\begin{array}{l}33 \\
(60 \%)\end{array}$ & $\begin{array}{l}18 \\
(32.7 \%)\end{array}$ & 0 \\
\hline 0 & $7(12.7 \%)$ & $\begin{array}{l}34 \\
(61.8 \%\end{array}$ & $\begin{array}{l}12 \\
0)(21.8 \%)\end{array}$ & $2(3.6 \%)$ \\
\hline 0 & $4(7.3 \%)$ & $\begin{array}{l}34 \\
(61.8 \%\end{array}$ & $\begin{array}{l}17 \\
0)(30.9 \%)\end{array}$ & 0 \\
\hline 0 & $7(12.7 \%)$ & $\begin{array}{l}33 \\
(60 \%)\end{array}$ & $\begin{array}{l}14 \\
(25.5 \%)\end{array}$ & $1(1.8 \%)$ \\
\hline 0 & $3(5.5 \%)$ & $\begin{array}{l}31 \\
(56.4 \%\end{array}$ & $\begin{array}{l}20 \\
0)(36.4 \%)\end{array}$ & $1(1.8 \%)$ \\
\hline
\end{tabular}

The results indicate that the students perceive the five lessons as relevant to the ability to function in intercultural contexts. The numbers range from $56.4 \%-61.8 \%$ for agree, $21.8 \%-36.4 \%$ for strongly agree and $5.5 \%-12.7 \%$ for disagree.

\section{Discussion}

This preliminary and exploratory study of a sociocultural approach and globalisation-related topics in teaching English to undergraduates has shown that the former motivates the students to learn English and seek for higher communication skills and the students perceive the latter as relevant to the ability to function in intercultural contexts.

While it may be true that $60 \%$ of the increase in foreigners are from China and Korea and $20 \%$ from Brazil and Peru (1. Introduction), English is East Asia's primary lingua franca (Kirkpatrick, 2011) and is going to play an important role as the number of foreigners in Japan continues to increase. The grammar-translation method is inadequate for preparing the Japanese for intercultural communication and complementing it with a sociocultural approach and globalisation-related topics seems promising.

Due to the way English has been taught, many Japanese are proficient in translating between English and Japanese but at a loss when they find themselves in situations which require English. Yano (2011) describes this as a lack of ability to use English in business negotiations, academic presentations or discussions. A sociocultural approach appears to be promising as it would impart valuable sociolinguistic knowledge about the norms of language use.

\section{References}

Baker, W. (2012). From cultural awareness to intercultural awareness: Culture in ELT. ELT Journal 66(1), 62-70.

Bostwick, M. (2001). Bilingual education of children in Japan: Year four of a partial immersion programme. In M. G. Noguchi, \& S. Fotos (Eds.), Studies in Japanese bilingualism (pp. 272-311). Clevedon: Multilingual Matters. 
Burgess, C. (2013, May 21). Ambivalent Japan turns on its 'insular' youth: System discourages overseas study but students get blame. The Japan Times. Retrieved from http://www.japantimes.co.jp/community/2013/05/21/issues/ambivalent-japan-turns-on-its-insular-youth/

Cheung, C.-K. (2001). The use of popular culture as a stimulus to motivate secondary students' English learning in Hong Kong. ELT Journal, 55(1), 55-61.

Davis, N. (1999). The globalisation of education through teacher education with new technologies: A view informed by research. Educational Technology Review, 12, 8-12.

Dornyei, Z. (1994). Motivation and motivating in the foreign language classroom. The Modern Language Journal, $78(3), 273-284$.

Georgiou, S. I. (2012). Reviewing the puzzle of CLIL. ELT Journal, 66(4), 495- 504.

Griffiths, C. (2011). The traditional/communicative dichotomy. ELT Journal, 65(3), 300-308.

Hayashi, H. (2005). Identifying different motivational transitions of Japanese ESL learners using cluster analysis: Self-determination perspectives. JACET Bulletin, 41, 1-17.

Hymes, D. H. (1972). On communicative competence. In J. B. Pride, \& J. Holmes (Eds.), Sociolinguistics (pp. 269-293). Harmondsworth: Penguin.

Kikuchi, K., \& Sakai, H. (2009). Japanese learners' demotivation to study English: A survey study. JALT Journal, 31(2), 183-204.

King, J. (2013). Silence in the second language classrooms of Japanese universities. Applied Linguistics, 34(3), 325-343.

Kirkpatrick, A. (2011). English as an Asian lingua franca and the multilingual model of ELT. Language Teaching, $44(2), 212-224$.

Knight, J., \& de Wit, H. (1995). Strategies for the internationalisation of higher education: Historical and conceptual perspectives. In H. de Wit (Ed.), Strategies for the internationalisation of higher education. Amsterdam: EAIE.

Lave, J., \& Wenger, E. (1991). Situated learning: Legitimate peripheral participation. Cambridge: Cambridge University Press.

Lingley, D. (2006). A task-based approach to teaching a content-based Canadian studies course in an EFL context. Asian EFL Journal, 8, 122-139.

Lyster, R., \& Ballinger, S. (2011). Content-based language teaching: Convergent concerns across divergent contexts. Language Teaching Research, 15(3), 279-288.

Morita, L. (2010). The sociolinguistic context of English education in Japan and Singapore. Electronic Journal of Contemporary Japanese Studies. http://www.japanesestudies.org.uk/discussionpapers/2010/Morita.html

Morita, L. (2013). Globalisation, intercultural contexts and the sociocultural component of an English course. Journal of English as an International Language, 8(1), 55-68.

Moriyoshi, N. (2010). Content-based instruction in Japanese college classrooms: Focusing on language, content, or both? Unpublished master's thesis, McGill University.

O’Donnell, K. (2003). Uncovering first year students' language learning experiences, attitudes, and motivations in a context of change at the tertiary level of education. JALT Journal, 25(1), 31-62.

Rahimi, M., \& Noroozisiam, E. (2013). The effect of strategies-based instruction on the improvement of EFL learners' writing quality: A sociocultural approach. Sage Open, 3, 1-8.

Richards, C. (2004). From old to new learning: Global imperatives, exemplary Asian dilemmas and ICT as a key to cultural change in education. Globalisation, Societies and Education, 2(3), 337-353.

Rogoff, B., \& Lave, J. (eds.) (1984). Everyday cognition. Cambridge, MA: Harvard University Press.

Romaine, S. (2000). Language in society: An introduction to sociolinguistics. Oxford: Oxford University Press.

Seargeant, P. (2009). The idea of English in Japan: Ideology and the evolution of a global language. Bristol: Multilingual Matters.

Stewart, A., \& Miyahara, M. (2011). Parallel universes: globalization and identity in English language teaching at a Japanese university. In P. Seargeant (Ed.), English in Japan in the era of globalization (pp. 60-79). Basingstoke: 
Palgrave Macmillan.

Suzuki, A. (2011). Introducing diversity of English into ELT: Student teachers' responses. ELT Journal, 65(2), 145-153.

The Council on Promotion of Human Resource for Globalization Development. (2011). An interim report of the Council on Promotion of Human Resource for Globalization Development. Retrieved 24 August, 2013, from, http://www.kantei.go.jp/jp/singi/global/1206011interim_report.pdf

Van Compernolle, R. A., \& Williams, L. (2012). Teaching, learning, and developing L2 French sociolinguistic competence: A sociocultural perspective. Applied Linguistics, 33(2), 184-205.

Vygotsky, L. (1986). Thought and language. Cambridge, MA: MIT Press.

Vygotsky, L. (1978). Mind in society: The development of higher psychological processes. Cambridge, MA: Harvard University Press.

Whitsed, C., \& Wright, P. (2011). Perspectives from within: Adjunct, foreign, English-language teachers in the internationalization of Japanese universities. Journal of Research in International Education 10(1), 28-45.

Yamagami, M., \& Tollefson, J. W. (2011). Elite discourses of globalization in Japan: The role of English. In P. Seargeant (Ed.), English in Japan in the era of globalization (pp. 15-37). Basingstoke: Palgrave Macmillan.

Yano, Y. (2011). English as an international language and 'Japanese English'. In P. Seargeant (Ed.), English in Japan in the era of globalization (pp. 125-142). Basingstoke: Palgrave Macmillan. 